\title{
YIELD AND BOTANICAL COMPOSITION OF BIRD'S-FOOT-TREFOIL CULTIVARS IN TWO-COMPONENT MIXTURE WITH KENTHUCKY BLUEGRASS
}

\author{
B. Churkova* \\ Department of Mountain Grassland Association and Maintenance of Their Biological Diversity, \\ Research Institute of Mountain Stockbreeding and Agriculture, Troyan, Bulgaria
}

\begin{abstract}
PURPOSE of the experiment is to study the influence of bird's-foot-trefoil cultivars of different origins over the productivity and quality of forage when they are grown together with Kenthucky bluegrass. METHODS: In the period of 2013-2015, in the experimental field of RIMSA-Troyan the productivity and botanical composition of bird's-foot-trefoil cultivars were studied, such as 'Targovishte 1', 'Delpon' (France), 'Fabio' (Italy), 'Haki' (Hungary), 'Vega' (USA) in two-component mixtures with Kenthucky bluegrass ('Sobra' cultivar).

RESULTS: The share of sown species and cultivars in the mixed grasslands of bird's-foot-trefoil and Kenthucky bluegrass depends on their biological characteristics, combined with the climatic and soil characteristics of the area. 'Fabio' cultivar shows the most pronounced adaptability to the soil climatic conditions of the region compared to all other bird's-foot-trefoil cultivar.

CONCLUSIONS: For the conditions of the Central Balkan Mountain, It is recommended to use the two-component mixture: bird's-foot-trefoil ('Delpon') and Kenthucky bluegrass ('Sobra'), which has the best intercompatibility and the most favourable combination of grass and legume component. The latter cultivar in the mixture recorded the highest average yields $(650.37 \mathrm{~kg} / \mathrm{da}$ dry weight) for the three-year study period, compared to other cultivars included in the experiment.
\end{abstract}

Key words: grass mixtures, bird's-foot-trefoil, Kenthucky bluegrass, productivity, botanical composition

\section{INTRODUCTION}

Bird's-food-trefoil as a perennial legume has an important role in the establishment of highproductive artificial grasslands. The advantages of various bird's-foot-trefoil cultivars are described in many studies. They are characterized by significant hay-mowing qualities, such as durability (1), cold and drought resistance, good yield in the later stages of grassland life $(2,3)$, resistance to phosphorus-poor and high concentrations of aluminum and manganese soils (4). The high degree of intrapopulation variability and bird'sfoot-trefoil allogamy allow the rapid genetic change in genotype of cultivars in co-

\footnotetext{
*Correspondence to: $B$. Churkova, Department of Mountain grassland association and maintenance of their biological diversity, Research Institute of Mountain Stockbreeding and Agriculture, Troyan, Bulgaria, e-mail: bchurkova@abv.bg
}

cultivation with appropriate grass meadows (5, 6 ). The overall sustainability and durability of cultivars is a function of the interaction between environmental conditions and their use. The genotypic results of this interaction are the cultural eco-types (7) suitable for joint cultivation in a specific region, using a specific agronomic practice $(8,9)$. They are of significant in the consolidation of gene plasm with hay-mowing tolerance, stamping during grazing, high yield and forage quality (10). The bird's-foot-trefoil cultivars of different origins (11), which are tested with the same grass cultivar component, under the same soil climatic conditions, behave in a different manner in relation to different indicators related to productivity and quality (12). Appropriate components for co-cultivation of bird's-foot-trefoil are Kenthucky bluegrass, timothy-grass, cock's foot and red fescue. 
Therefore, the main aim of the experiment is to study the influence of bird's-foot-trefoil cultivars of different origins over the productivity and quality of forage when they are grown together with Kenthucky bluegrass.

\section{MATERIAL AND METHODS}

The experiment was carried out in 2013-2015 in the experimental field of RIMSA-Troyan, using the block method in four repetitions, with a plot size of $5 \mathrm{~m}^{2}$. The following bird'sfoot-trefoil cultivars are studied in twocomponent mixtures together with Kenthucky bluegrass ('Sobra'): 'Targovishte 1', 'Delpon' (France), 'Fabio' (Italy), 'Haki' (Hungary), 'Vega' (USA). The traditional cultivation technology of artificial grasslands for this region is applied. The main fertilization is carried out with phosphorus and potassium as a reserve application at a dose of $400 \mathrm{~kg} \mathrm{ha}^{-1}$ $\mathrm{P}_{2} \mathrm{O}_{5}$, and the pre-sowing with $\mathrm{N} 60 \mathrm{~kg} \mathrm{ha}^{-1}$ once. The sowing is manual, scattered, with a sowing rate for bird's-foot-trefoil in pure state of $12.0 \mathrm{~kg} \mathrm{ha}^{-1}$, while for Kenthucky bluegrass is $20 \mathrm{~kg} \mathrm{ha}^{-1}$. The mixture of Bulgarian bird'sfoot-trefoil cultivar 'Targovishte 1' and Kenthucky bluegrass is used as a standard.

During the three years of the experimental period, two regrowths were harvested in hay
CHURKOVA B.

harvesting stage in the phase of bud-formation period - beginning of blossoming of bird'sfoot-trefoil. The botanical composition of the grassland (\%) is determined by analyzing the fresh matter samples taken at each mowing from each variation. The weighing is measured in an air dry state, as the percentage share of sown grass species and motley grasses is determined.

Dry vegetative matter yield $(\mathrm{kg} / \mathrm{da})$ is determined by drying the average samples (200 g) in laboratory conditions to a constant weight at $105{ }^{\circ} \mathrm{C}$. Dry matter yield is calculated according to regrowths, years and average for the experimental period based on green matter yield and dry matter content.

The dry matter yield results were processed by dispersion analysis method using Analysis Toolpak software for Microsoft Excel 2010 and Statgraphics Plus v.2.1.

\section{RESULTS}

The experimental years differed significantly in terms of the precipitation rainfall. (Figure 1). The driest year was 2015 when the precipitation amount during the vegetation period was $549.5 \mathrm{~mm}$. For 2014, it was 222.6 mm higher than those in 2015.

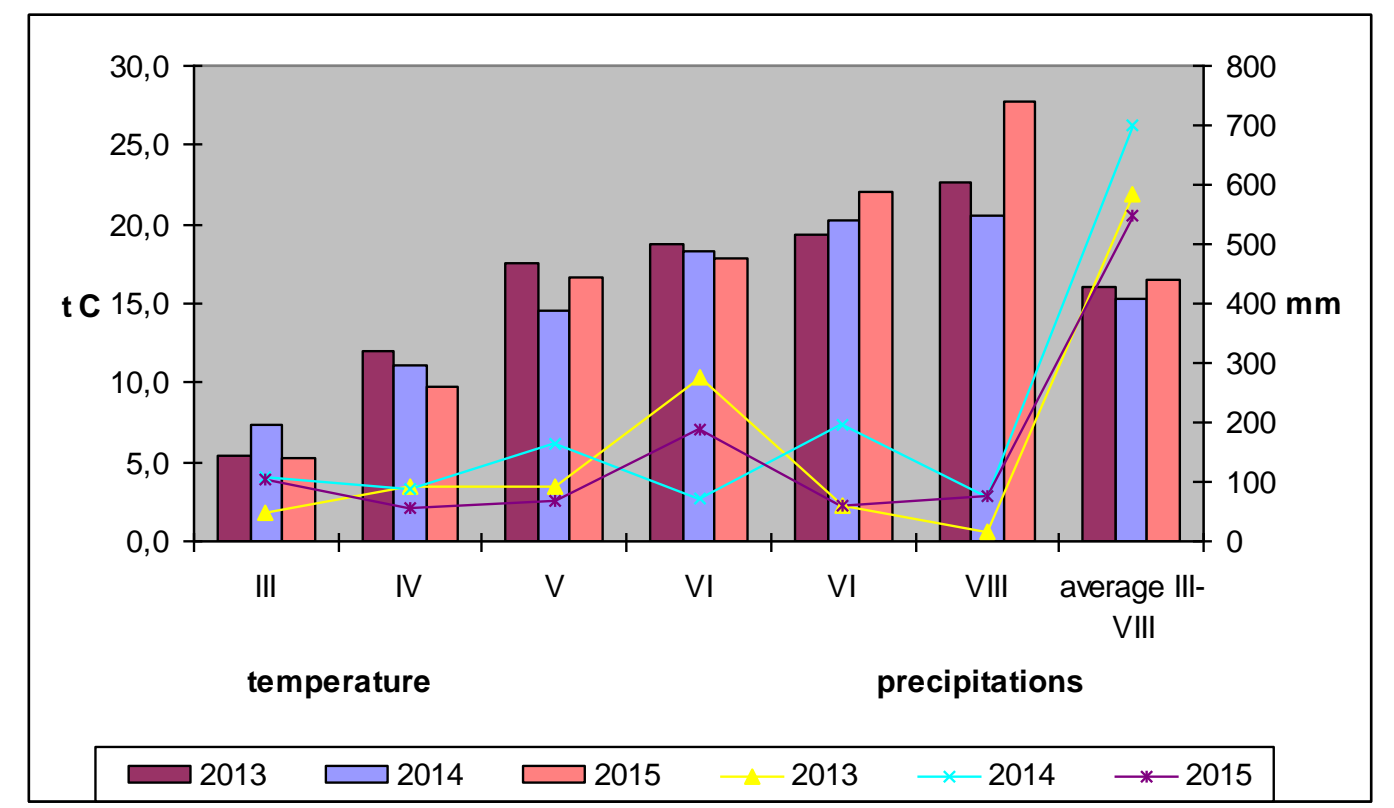

Figure 1. Average monthly temperatures $\left({ }^{0} \mathrm{C}\right)$ and monthly precipitation amounts $(\mathrm{mm})$ in the vegetation period by years

The spring is relatively cool and well-provided with precipitation in the year of sowing, which favours the normal development of crops. Since the active vegetation starts at an air temperature above $5^{\circ} \mathrm{C}$, the average temperature of $5.4^{\circ} \mathrm{C}$ measured in March is suitable for the normal germination of bird'sfoot-trefoil. The average air temperature for 
the vegetation period over the three years varies within small limits (16.0, 15.3 and 16.5 $\left.{ }^{\circ} \mathrm{C}\right)$.

Table 1 shows the dry matter yield per year and average over the period. In the first year the yield varies considerably depending on the cultivar. It is mainly determined by bird's-foottrefoil, and the grass component in the mixture has influenced the growth and development of the legume crop in both regrowths. The biological characteristic of sown crops is the reason: type of development, adaptability to soil acidification, mode of use, etc.

There is a lower productivity of the mixtures with the tested cultivars compared to the mixture where 'Targovishte 1' cultivar is involved. Only the grass mixture of bird's-foottrefoil 'Fabio' cultivar + Kenthucky bluegrass slightly exceeds the control by only $5.25 \%$. The yield of bird's-foot-trefoil 'Vega' cultivar + Kenthucky bluegrass mixture is less productive than the control with $12.41 \%$. A yield close to the control was recorded in the mixture of bird's-foot-trefoil 'Delpon' cultivar+Kenthucky bluegrass.
CHURKOVA B.

In the second year, the mixture of bird's-foottrefoil 'Vega' cultivar with Kenthucky bluegrass had the highest productivity, with a dry matter yield of $1380.84 \mathrm{~kg} / \mathrm{da}$, exceeding the control by $16.21 \%$, and the excess compared to the control was also statistically proven. The rest of the bird's-foot-trefoil cultivars show a much lower yield in cocultivation with Kenthucky bluegrass. Productivity compared to the first and third vegetation is highest, expressed in numbers, respectively, from 888.52 to $1380.84 \mathrm{~kg} / \mathrm{da}$. The high numerical values of dry matter yield are the result of maximum growth rate and development of legume component and favorable climatic conditions.

Data analysis shows that in the second vegetation, the mixed grasslands, consisting of different bird's-foot-trefoil and Kenthucky bluegrass cultivars, grown in non-irrigated conditions, are characterized by a stronger yield variation. This proves the different adaptability of the cultivars to the soil-climatic conditions of cultivation, which determines the compatibility of both species to the mountainous conditions of Central Balkan Mountain and confirms the results by Karadag (2004).

Table 1. Dry matter yield in years and average over the period

\begin{tabular}{lcccccccc}
\hline \multicolumn{1}{c}{ variant } & \multicolumn{2}{c}{2013} & \multicolumn{2}{c}{2014} & \multicolumn{2}{c}{2015} & \multicolumn{3}{c}{$\begin{array}{c}\text { Average for the } \\
\text { period }\end{array}$} \\
\cline { 2 - 9 } & $\mathrm{kg} / \mathrm{da}$ & $\%$ & $\mathrm{~kg} / \mathrm{da}$ & $\%$ & $\mathrm{~kg} / \mathrm{da}$ & $\%$ & $\mathrm{~kg} / \mathrm{da}$ & $\%$ \\
\hline $\begin{array}{l}\text { Targovishte 1 } \\
+\quad \text { Kenthucky } \\
\text { bluegrass }\end{array}$ & 549.5 & 100.0 & 1188.2 & 100.0 & 497.9 & 100.0 & 462.5 & 100.0 \\
$\begin{array}{l}\text { Delpon + } \\
\text { Kenthucky } \\
\text { bluegrass }\end{array}$ & 543.9 & $98.9-$ & 1002.4 & $84.40-$ & 777.2 & $156.1+++$ & 650.4 & $140.6+++$ \\
$\begin{array}{l}\text { Fabio + } \\
\text { Kenthucky } \\
\text { bluegrass }\end{array}$ & & & & & & & & \\
$\begin{array}{l}\text { Haki + } \\
\text { Kenthucky }\end{array}$ & 578.4 & $105.2-$ & 910.2 & $76.6-$ & 678.8 & $136.3+++$ & 574.1 & $124.1+++$ \\
bluegrass & 506.9 & $92.2-$ & 888.5 & $74.8-$ & 684.9 & $137.5+++$ & 576.1 & $124.6+++$ \\
$\begin{array}{l}\text { Vega + } \\
\text { Kenthucky } \\
\text { bluegrass }\end{array}$ & 481,4 & $87.6-$ & 1380.8 & $116.2+$ & 723.0 & $145.2+++$ & 575.7 & $124.5+++$ \\
\hline $\begin{array}{l}\text { GD 5\% } \\
\text { GD 1\% }\end{array}$ & 120,5 & 21,9 & 162,4 & 13,7 & 41,1 & 8,3 & 39,6 & 8,6 \\
GD 0,1\% & 169,2 & 30,8 & 227,9 & 19,2 & 57,7 & 11,6 & 55,6 & 12,0 \\
\hline
\end{tabular}

In the third year of the experimental period, all bird's-foot-trefoil cultivars are significantly more productive than the control mixture with mathematically very good evidence of differences. The Kenthucky bluegrass mixtures with 'Delpon' and 'Vega' cultivars deliver maximum productivity with a dry matter yield of 777.1 and $723.0 \mathrm{~kg} / \mathrm{da}$, exceeding the control by 56.1 and $45.2 \%$. The development and cultivation of Kenthucky bluegrass is strongly dependent on the precipitation amount and the rate and type of grass development that determine the high dry matter yield this year. In 2015 , the annual precipitation amount is 
$922.7 \mathrm{~mm}$ (with an average multi-year 718.7 $\mathrm{mm})$. Compared to the previous vegetation, the rainfall in May and July in the same year is less, and the average vegetation temperatures this year are higher by $1.6^{\circ} \mathrm{C}$. Higher temperatures and lower average daily air humidity have influenced the productive potential of legumes and grass forage. In the third experimental year, grasslands in all variants reported the highest values for this indicator compared to controls when both crops showed the highest growth and development rates. The dry matter yield data are reported and correlated with those for botanical composition. The high relative share of both components in grasslands in all variants also determines their high productivity.

Compared to the control, the productivity of all mixtures average over the period was significantly higher. The yield and dry matter indicators ranges from 574.11 to $650.37 \mathrm{~kg} / \mathrm{da}$. The grassland of bird's-foot-trefoil 'Delpon' and Kenthucky bluegrass has the highest dry matter yield, and the grasslands of the other bird's-foot-trefoil cultivars grown in the mixture are almost identical to this index. The trend we see on average for the period 20132015 determines the mixed the mixed grassland of 'Delpon' Star Fertilizer and Kenthucky bluegrass as the most productive, with an excess in comparison with the control of $40.61 \%$. This shows the good adaptability of this bird's-foot-trefoil cultivar, which makes it
CHURKOVA B.

suitable for co-cultivation with meadow grass under the conditions of light gray pseudopodzolic soils. The present study data prove that the differences in the stability of forage yield are the result of the genotype $\mathrm{x}$ environment relationship, whose strength depends on the genetic composition of the cultivar and on the intensity of impact of a particular environmental factor.

The grassland botanical composition (Figure 2) shows that in the first experimental year, the bird's-foot-trefoil of all varieties is present with a significantly high relative share in the grassland. The share participation of 'Fabio' cultivar is $72.4 \%$ in the mixture with Kenthucky bluegrass. Therefore, the higher yields reported in the grassland are due to bird's-foot-trefoil, not to Kenthucky bluegrass. The grass component has an insignificant amount in the grassland in the mixtures with all tested bird's-foot-trefoil cultivar, which is explained by its growth and development rate. Kenthucky bluegrass is a typical grazing grass, and when it is used as intended, it grows intensively throughout the growing season, but in the first year its development is suppressed and its share in the grassland has reached only 5.5 to $10.0 \%$. The weeds range from $20.7 \%$ to $33.3 \%$, confirming Vasileva and Vasilev (12) that the perennial grasses in the mixtures are characterized by a slow growth rate in the first year, resulting in grasslands with high weed infestation and low forage productivity.

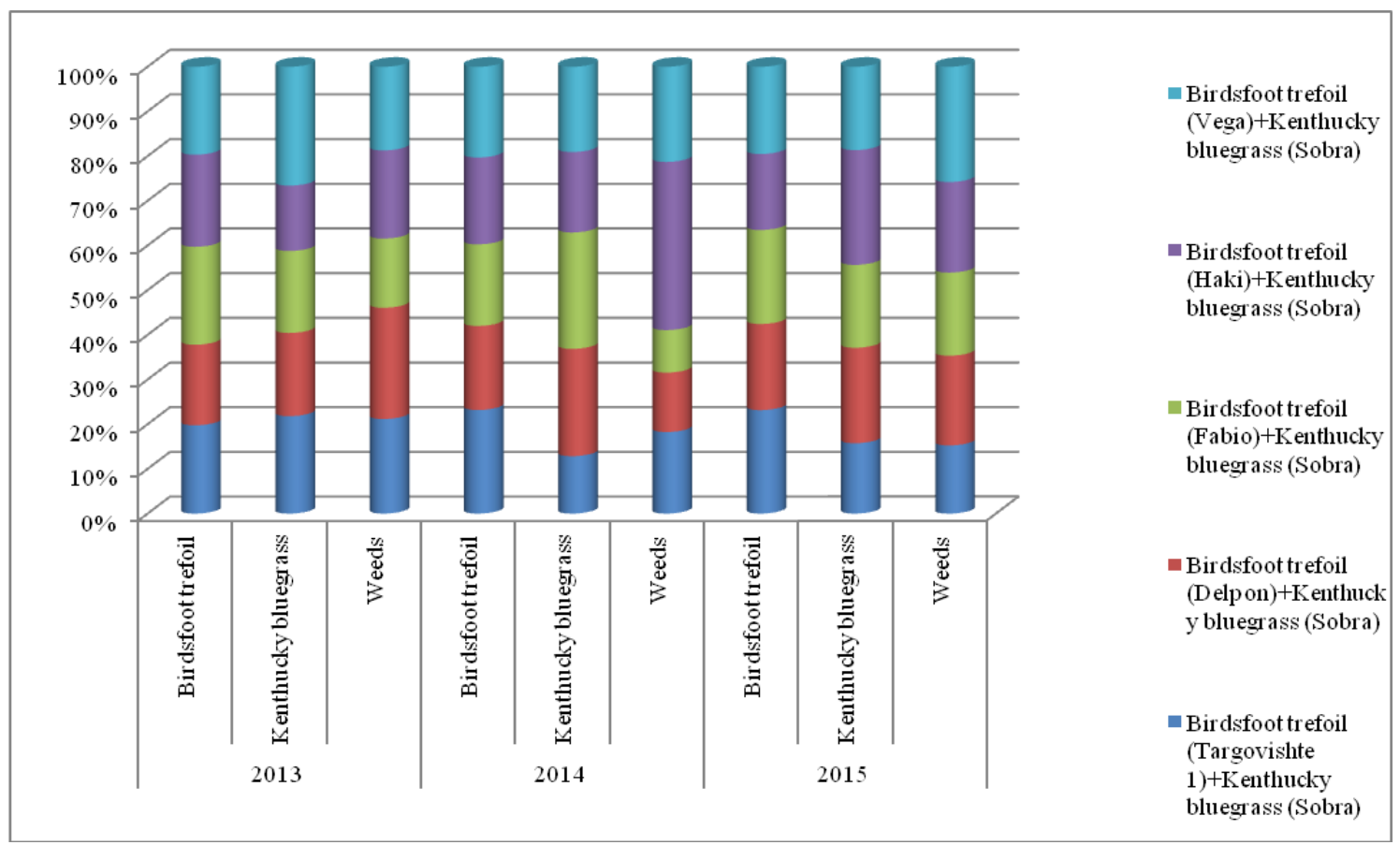

Figure 2. Botanical composition of grassland, weight percentage 
In the second year, the percentage of bird'sfoot-trefoil 'Vega' cultivar is $67.4 \%$ in its mixture with Kenthucky bluegrass. In all variants, the relative share of bird's-foot-trefoil is twice as large as that of the meadow fescue. Here, as in the first year, the higher yields reported in the grassland are due to bird's-foottrefoil, not to Kenthucky bluegrass. Slow growth and development of meadow fescue explains its slight presence in the grassland. The share of weeds in all variants is very low, from 2.5 to $9.9 \%$, which confirms the statement that mixed grasslands reduce the grassing of the grassland. The proportion of bird's-foot-trefoil 'Delpon' cultivar: Kenthucky bluegrass is: $62.5: 34.0 \%$, which is an indicator of a good compatibility at cultivar level and implies a significant effect on the quality and nutritional value of the mixture. It is also beneficial to combine the other three cultivars in mixed crops. The mixture of Kenthucky bluegrass with bird's-foot-trefoil 'Fabio' cultivar has a more balanced botanical composition (36.9:60.6\%) and the lowest weed infestation (2.5\%), which is associated with a high ecological plasticity and an adaptability of the tested crops and cultivars thereof, higher quality and nutritional value of the harvested grass matter.

In the third year with the exception of 'Delpon' cultivar, the percentage of bird's-foot-trefoil in other cultivars is relatively high. The share of 'Haki' cultivar is $70.4 \%$ in its mixture with Kenthucky bluegrass, and the weeds are very low in all variants, from 9.1 to $27.8 \%$, respectively. This confirms Bozhanska's statement (13) that productivity and botanical composition as indicators of sustainability and quality of harvested biomass are directly dependent on the ecological conditions and their cultivation. Mixtures of the different cultivars of bird's-foot-trefoil with meadow fescue have a greatly reduced composition of grass components. Legume grass is a determinant in the yield of all variants and has a high presence in the grassland $(67.3 ; 56.0$; $61.1 ; 49.4 ; 56.7 \%)$, while the share of Kenthucky bluegrass $(32.0 ; 27.8 ; 38.5$ and $27.9 \%$ ) is low; both components show good compatibility. In terms of the comparatively dry climate in 2015 , the better realization and productivity of Kenthucky bluegrass is due to its short underground roots, which in the autumn or in wet weather form new stems and increase its resistance to unfavorable environmental factors.

\section{CONCLUSIONS}

CHURKOVA B.

The appropriately selected cultivar of bird'sfoot-trefoil in co-cultivation with Kenthucky bluegrass in two-component mixtures result in more and better balanced forage. On average, during the study period, the mixture of bird'sfoot-trefoil 'Delpon' cultivar with Kenthucky bluegrass (650.37 kg/da dry mass) was most productive, and the yields of 'Fabio', 'Haki' and 'Vega' varieties were almost similar. The different adaptability and intercompatibility of grass and legume component and its cultivars have a strong influence on the productive potential of the grassland.

The share of sown species and cultivars in the mixed grasslands of bird's-foot-trefoil and Kenthucky bluegrass depends on their biological characteristics, combined with the climatic and soil characteristics of the area. The adaptability of 'Fabio' cultivar to the soil climatic conditions of the region is most pronounced of all bird's-foot-trefoil cultivars.

For the conditions of the Central Balkan Mountains, it is advisable to use the twocomponent mixture: bird's-foot-trefoil ('Delpon') and Kenthucky bluegrass ('Sobra'), which produces the highest productivity,

\section{REFERENCES}

1. Lugic, Z., Ignjatovic S., Lazarevic D., Radovic J., Dinic B., Investigation of some important characteristics of different genotypes of white clover (Trifolium repens L.) in agroecological conditions of Serbia. Journal of mountain agriculture on the Balkans, 7-5:518-525, 2004.

2. Mitev, D., Mihovski Ts., Churkova B., Durability of artificial grasslands with the participation of red fescue, situated on the slopes of the Central Balkan Mountain. 9. Condition of mixed grasslands of red fescue, cock's-foot, red clover and bird'sfoot trefoil. Journal of Mountain Agricultural on the Balkans, 13 (6):15941605, 2010.

3. Vasileva V., Productivity of dry ground and root mass in grass mixtures. Journal of Mountain Agriculture on the Balkans, 17 (4): 956-969, 2014.

4. Mitev, D., Naydenova G., Sustainable development of mixed grassland of red fescue and Kenthucky bluegrass on the slopes of the Central Balkan Mountains. "Ecology-Sustainable Development" Vratsa, pp 96-100, 2008.

5. Karadag, Y., Forage yields, seed yields and 
botanical compositions of some legume barley mixtures under rain fed conditions in semi-arid regions in Turkey. Asian Journal of Plant Sciences, .3 (3):295-299, 2004.

6. Mitev, D., Churkova B., Iliev M., Comparison of some grasses and legumes under conditions of Central Balkan Mountains. Journal of Mountain Agriculture on the Balkans, 16 (5): 12351246, 2013.

7. Mitev, D., Adaptability of some cultivars and populations of legume meadow grasses to the ecological variations in the region of the Central Balkan Mountain. Journal of Mountain Agricultural on the Balkans, 17:1178-1186, 2014.

8. Vasileva V., Botanical composition improvement with subterranean clover (Trifolium subterraneum L.) in grass mixtures. Journal of Applied Sciences, 16 (2):68-76, 2016.

9. Scheffer-basso, S., Brustolin R., Dall'agnol M., Performance of Lotus corniculatus L. genotypes submitted to cutting interval: subsidies to a breeding program. Revista
CHURKOVA B.

Brasileira de Zootecnia, 40 (8):http://dx.doi.org/10.1590/S1516$35982011000800004,2011$.

10.Radovic, J., Dinic B., Pudio V., Productivity and Quality of Some birdsfoot trefoil (Lotus corniculatus L.) Varieties. Proceedings of the 12th Symposium of the European Grassland Federation, Pleven, Bulgaria, 26 - 28 MAY, 118 - 121, 2003.

11. Naydenova, Y., Chakarov R., Pavlov D., Plant cell walls fiber components content and digestibility of wheatgrass (Agropyron cristatum L.), grown in pure stand and in mixtures with perennial legumes. Journal of Animai Science, Sofia, 42 (5):121-128, 2005.

12. Vasileva, V., Vasilev E., Study on productivity of some legume crops in pure cultivation and mixtures. Agriculturae conspectus scientificus, 77 (2):91-94, 2012.

13.Bozhanska, T., Productivity and qualitative characteristics of forage grasses and grass mixtures under conditions of the Central Balkan Mountain. Dissertation, Troyan, 2017. 